\title{
Invention of Waste Assimilator for Biodegradable Solid Waste Management and Organic Farming
}

\author{
Amarjyoti Kashyap ${ }^{1 *}$ and Ruli Borthakur ${ }^{2}$ \\ ${ }^{1}$ President, ENVIRON, Guwahati, Assam, India \\ ${ }^{2}$ Department of Zoology, Arya Vidyapeeth College, Guwahati, Assam, India \\ *Corresponding Author: Amarjyoti Kashyap, President, ENVIRON, Guwahati, Assam, India.
}

Received: August 23, 2019; Published: September 09, 2019

DOI: 10.31080/ASAG.2019.03.0646

\begin{abstract}
Present scenario of mixing of plastic waste along with the biodegradable solid waste are ruined the entire solid waste management activities and developing huge 'waste land' and 'toxic land' day by day in India. To fulfill the requirement, a "Waste Assimilator" is invented (Patent Application No. 1352/KOL/2014) to produce 'bio-pest repellent' and 'organic manure' in the form of Macro and Micro 'Plant nutrients', 'Vermiwash' and finally 'Vermicompost' at household level by utilizing all type of daily generated biodegradable solid waste including Kitchen waste, Fruit and Vegetable peels, Meat and Fish waste, Agricultural waste, Garden waste, Forest waste, Water hyacinth etc. The invention is now generating the concept of solid waste management and 'organic farming' including household level domestic 'organic green Tea' gardening which is also opening a path for economic growth and health benefits out of the waste resources. Through the use of "Waste Assimilator", up to $80 \%$ domestic solid waste problem can be solved and a significant reduction of the roadside dumps can be achieved. On the other hand, bigger size community "Waste Assimilator" can manage the community or market generated biodegradable solid waste which can inspire large scale organic farming in rural areas.
\end{abstract}

Keywords: Plastic Waste; Biodegradable Solid Waste; Waste Assimilator; Plant Nutrients; Organic Farming; Organic Green Tea

\section{Existing competing solutions}

Several technologies and products are known that makes use of bio-degradable waste and converts them into vermicompost. For example

- Patent No.IN181279: Prefabricated Vermicompost Plant relates to a specially designed prefabricated vermicompost plant intended for manufacturing natural fertilizer from organic waste. But, it is not feasible at household level in terms of size, manpower requirement, conduciveness for single family operation and maintenance on a daily household basis. Deposition of biodegradable waste is biweekly and maximum 'for two times and for the next 30 days, the tank should not be disturbed but kept moist by watering whenever necessary'. Local soil eater earthworm might be collected from soil (otherwise cannot survive in soil) and also used loamy soil into which earthworm are inoculated. Soil is necessary for the survival of earthworm. Cow dung is also necessary. In order to keep the unit moist a system of pipeline and sprinkling water system is installed on top of the tank. No system for the collection of Vermiwash.

- $\quad$ Patent No.CA2761494: Worminator is specially designed for the compact residential compost making methodology from the household food waste that would provide basic composition and ingredients to make Compost Tea. However, it is complicated in structure and operation and is not possible for daily household use. Also, there is no system for the collection of Vermiwash.

- $\quad$ Patent No.KR1012950850000: The vermicomposting system for the city agriculture and ecological education is highly complicated in structure and operation, specially designed for vermicomposting but not possible for daily household use and there is no system for the collection of Vermiwash. 
- $\quad$ Patent No.US7964385: Organic Waste Treatment System Utilizing Vermicomposting is highly complicated and sophisticated in structure and operation and not possible for daily household use. No system for the collection of Vermiwash.

- US7964385: Organic Waste Treatment System Utilizing Vermicomposting is Highly complicated and sophisticated in structure and operation and not possible for daily household use. No system for the collection of Vermiwash.

- Patent No.IN231000: A Novel and Efficient Method for Production of Superior Quality Vermicompost from the Distillation Wastes of Aromatic/Medical Crops is limited to production of superior quality vermicompost from the distillation wastes of aromatic/medicinal crops. Also, there is no system for the collection of Vermiwash.

\section{Advantages of 'Waste Assimilator'}

This invention introduces an improved technology for composting of daily generated biodegradable solid waste through microbial aerobic digestion and assimilation by earthworm. It has an 'aeration layer' for faster microbial growth and rapid digestion of biodegradable solid waste. It is designed for household use with a very easy process of regular waste disposal above the composting bed without additional moistening system. As soil-eater earthworms cannot efficiently assimilate biodegradable solid waste, therefore, earthworm is collected from decayed banana plants (is a resistant variety of heat, generated from the pre-decomposed waste). Simple 'plastic cover' is enough over the assimilator. Fresh biodegradable waste consisting of water is enough to moisten the unit. It is simple in structure and operation and specially designed for the daily generated household biodegradable solid waste management offering continuous collection system of 'microbial wash', 'vermiwash' and finally 'vermicompost'.

Description of the domestic waste assimilator

- $\quad$ The size of the Domestic Waste Assimilator: height- 24 inch and diameter- 17 inch.

- It comprises of a cylindrical container [1] that is placed on a sturdy platform [2].

- The container [1] has a sloped base [3] that leads to an outlet [4].

- $\quad$ Above the base [3] is an aeration layer [5] made of dry bamboo culm pieces and above it is the composting area [6] where biodegradable solid waste is deposited.

- Above the composting area [6] is the ventilation system [7].
- $\quad$ All types of daily generated biodegradable solid waste can be directly deposited in the composting area on daily basis.

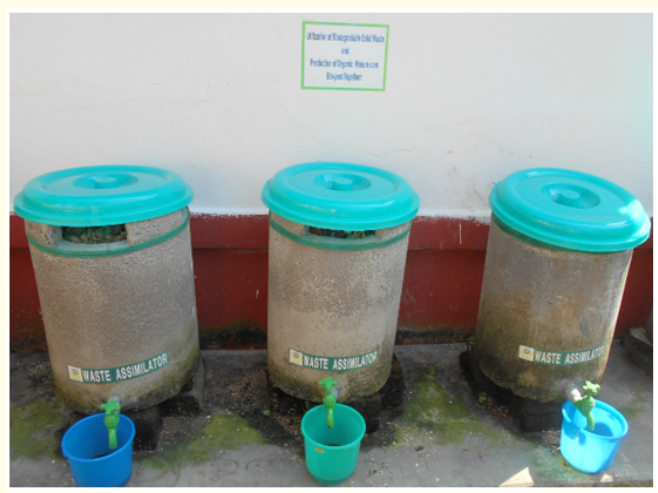

Figure 1: Domestic Waste Assimilator.

Description of community waste assimilator

- The size of the Community Waste Assimilator: Length15 feet, breadth- 11 feet and height 5 feet. Whereas roof height is 9.5 feet.

- It comprises of two rectangular chambers [1].

- The chamber [1] has a sloped base [2] that leads to an outlet [4].

- Above the base [2] is an aeration layer [3] made of dry bamboo culm pieces and above it is the composting area [5] where biodegradable solid waste is deposited.

- All types of daily generated biodegradable solid waste can be directly deposited in the composting area on daily basis.

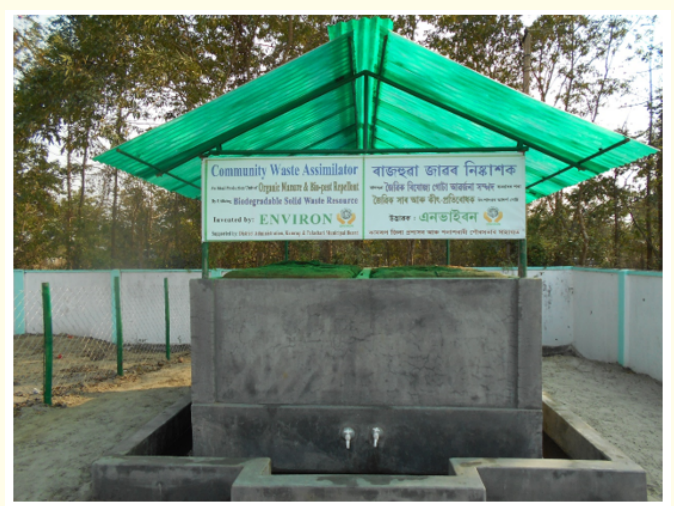

Figure 2: Community Waste Assimilator. 


\section{Method of operation}

For household level biodegradable solid waste management, a simplified technology of enhanced microbial growth with rapid aerobic microbial digestion along with the faster assimilation of biodegradable solid waste through a local varieties of earthworm is adopted inside a small Bin (capacity 70 litre) made of concrete and named as 'Waste Assimilator'. Biodegradable solid waste is deposited on daily basis inside the composting bed by opening the top cover of 'Waste Assimilator'. Simultaneously, rapid multiplication of microbial growth and aerobic digestion is taking place which becomes faster due to the aeration layer. Available water component inside the waste is favourable for the decomposition and a little sprinkle of water is necessary in case of dry biodegradable waste. In this process, per day, $1 \mathrm{~kg}$ to $3 \mathrm{~kg}$ biodegradable waste is deposited inside the 'Waste Assimilator' for 60-180 days until the filling of the 'Waste Assimilator'. During the process of waste deposition, after 25 days, 100 nos. of local varieties of earthworm are released inside the 'Waste Assimilator'. The earthworms immediately settle inside the decomposed waste and start assimilation of both decomposed and semi decomposed waste and accordingly rapid multiplication of the earthworms takes place due to the proper aeration facility and available food. Before the maximum multiplication of earthworm, excess water in the form of 'microbial wash' and after it is full of earthworm 'vermiwash' is collected through the outlet of the 'Waste Assimilator'. During the process of deposition of waste and its assimilation, two (2) nos. of 'Waste Assimilators' are required to maintain the continuous activity. For this, the use of the second assimilator is necessary after the first one is filled up. In this process, before the use of the 'second assimilator', the 'first one' gets filled up with vermicompost and earthworm and then transfers the multiple nos. of earthworms into the 'second assimilator' after sieving. This process continues simultaneously.

Through the 'Waste Assimilator', all the daily generated biodegradable solid waste can be managed at source by the assimilation of microbes and earthworm. The 'Assimilator' is designed in such a way that all the necessary scientific technology (like slopping base, aeration layer, ventilation) is fixed and no additional apparatus is required. Thus, a simplified technology is adopted for the assimilation of daily generated household biodegradable solid waste through microbes and earthworms. The use of the 'Waste Assimilator' is very simple and regularly usable for the disposal of the daily generated biodegradable solid waste [8-12].
Important feature

- Waste Assimilator is made up in 'Concrete Ring'.

- Very simple to use by adopting simply use and throw practice of biodegradable solid waste.

- $\quad$ Need a very little space and can be kept inside the balcony of an apartment.

- Can deposit all type of biodegradable waste and even along with water.

- A liquid 'microbial wash' is coming out constantly through the outlet after 2-3 days of the use of 'Waste Assimilator' which can be regularly used as 'Organic Manure'.

- A liquid 'vermiwash' is coming out constantly after the 'Assimilator' is full of earthworm through the outlet of the 'Waste Assimilator' which can be used both as 'organic manure' and 'bio-pest repellent'.

Nutritional component produced from the "Waste Assimilator"

Nitrogen, Phosphorus, Potash, Amino Acid, Enzymes, Organic Carbon, Calcium, Magnesium, Zinc, Iron along with Vitamins, different Hormones and many useful microbes.

\section{Bibliography}

1. Al-Khatib I A., et al. "Trends and problems of solid waste management in developing countries: a case study in seven Palestinian districts". Waste Management 27.12 (2007): 19101919.

2. Asha Aalok AK. "Vermicomposting: A Better Option for Organic Solid Waste Management". Journal of Human Ecology 24.1 (2008): 59-64.

3. Ahmed IM and Warsi T S. "Solid Waste Management in the Developing Countries". Icon SWM (2011): 58-69.

4. Arumugam K and Muthunarayanan V. "Vermicomposting of Vegetable-Market Waste Utilizing different Species of Earthworm". IconSWM (2011): 314-322.

5. Basu BK. "Effective Use of Daily Domestic Municipal Waste : A New Perspective Zero Budget Natural Farming \& Enzyme from Green Waste". IconSWM (2011): 201-209

6. Biswas S. "Composting of Solid Waste by Bacteria Extracted from Selected Earthworm Species". IconSWM (2011): 269275. 
7. Jadia CD and Fulekar M H. "Solid Waste Management, Development of Vermicompost in a Designed Aerobic Bioreactor". Icon SWM (2009): 94-97.

8. Kashyap A J., et al. "Analysis of municipal solid waste and its management practices in Guwahati". NeBIO 1.4 (2010): 30-34.

9. Kaviraj and SatyawatiSharma. "Municipal solid waste management through vermicomposting employing exotic and local species of earthworms". Bioresource Technology (2003): 169-173.

10. Singh WR., et al. "Evaluating Compost Stability of Water Hyacinth: Agitated Pile versus Rotary Drum Composting". IconSWM (2011): 293-299.

11. Slater R A and J Frederickson. "Composting municipal waste in the UK, some lessons from Europe. Resources, Conservation and Recycling 32 (2001): 359-374.

12. Visvanathan $\mathrm{C}$ and Glawe U. "Domestic Solid Waste Management in South Asian Countries - A Comparative Analysis". $3 R$ South Asia Expert (2006).

Volume 3 Issue 10 October 2019

(C) All rights are reserved by Amarjyoti Kashyap and

Ruli Borthakur. 